\title{
Pemidanaan Suami Menjual Istri Untuk Layanan Seks Menyimpang: Kajian Terhadap Korban Dalam Vonis Hakim
}

\author{
A Djoko Sumaryanto ${ }^{1}$ \\ Universitas Bhayangkara Surabaya, Indonesia \\ doi https://doi.org/10.32507/mizan.v4i2.686
}

\begin{abstract}
The applicable criminal law still adheres to the concept of Daad Dader Strafrecht, so that the existence of a crime victim has not been touched by the Act implemented in each judge's decision, such as the event of a husband selling his wife to serve deviant sex (threesome). The position of the wife in this case is a crime victim conducted by the husband. Using the method of normative legal research (legal research), with the statutory approach and cases (case approach), which examines the Sidoarjo District Court Decision number 889/Pid.Sus/2018/PN SDA, a result will be obtained that the application of the law is inadequate and the view still weak on the victim of crime who is his wife. The recommendations of this study are that Judim be more careful and observant in understanding the laws and regulations and sentences that have been given due attention to victims who are family members (wives).
\end{abstract}

Keywords: Criminal Law, crime victims, verdicts

\begin{abstract}
Abstrak
Hukum pidana yang berlaku masih berpegang pada konsep Daad Dader Strafrecht, sehingga keberadaan korban kejahatan belum terjamah oleh Undang-undang yang diimplementasikan dalam setiap putusan hakim, seperti peristiwa suami menjual istrinya untuk melayani seks menyimpang (threesome). Posisi istri dalam hal ini adalah korban kejahatan yang dilakukan oleh suami. Dengan menggunakan metode penelitian hukum normatif (legal research), dengan pendekatan perundang-undangan (statute approach) dan kasus (cases approach), yang mengkaji Putusan Pengadilan Negeri Sidoarjo nomor 889/Pid.Sus/2018/PN SDA, akan diperoleh suatu hasil bahwa kurang tepatnya penerapan Undang-undang dan masih lemahnya pandangan terhadap korban kejahatan yang adalah istrinya. Rekomendasi penelitian ini agar hakim lebih teliti dan jeli dalam memahami peraturan perundang-undangan serta vonis yang dijatuhkan telah memperhatikan korban yang adalah anggota keluarga (istri).
\end{abstract}

Kata Kunci: Hukum pidana, korban kejahatan, vonis

* Naskah diterima tanggal: 12 September 2020, direvisi: 13 Oktober 2020, disetujui untuk terbit: 10 Desember 2020.

${ }^{1}$ A Djoko Sumaryanto adalah dosen pada Universitas Bhayangkara Surabaya, Indonesia. E-mail: adjokosum@gmail.com 


\section{A. PENDAHULUAN}

Indonesia adalah negara yang berdasarkan hukum melindungi dan menjunjung Hak Asasi Manusia sebagaimana yang tertuang dalam Pasal 27 ayat (1) UUD 1945 menyatakan bahwa "Setiap warga negara bersamaan kedudukannya di dalam hukum dan pemerintahan dan wajib menjunjung hukum dan pemerintahan itu dengan tidak kecualinya". Prinsip ini seyogyanya tidak hanya sebagai slogan saja namun lebih utama adalah dalam mengimplementasikan dalam penegakan hukumnya.

Di zaman kemerdekaan ini, terlebih di era reformasi dengan kemajuan teknologi informasi dan komunikasi sering kali dimanfaatkan oleh pihak yang tidak bertanggung jawab untuk mendapatkan keuntungan dengan melakukan perbuatan di bidang kesusilaan yang korbannya adalah perempuan. Perdagangan manusia sebenarnya bukan merupakan hal baru, namun beberapa tahun belakang masalah ini muncul kepermukaan dengan berbagai modus operandi.

Beberapa faktor penyebab terjadinya hal tersebut adalah adanya diskriminasi gender, praktek budaya yang berkembang di masyarakat Indonesia, pernikahan dini, kawin siri, konflik dan bencana alam, putus sekolah, pengaruh globalisasi, sistem hukum dan penegakan hukum yang lemah, keluarga yang tidak harmonis, rendahnya nilai-nilai moral agama, dan sebagainya.

Perkembangan di dalam dan di luar manusia tertentu mempengaruhi kecenderungan dan kemampuannya untuk melakukan perilaku yang tercela, merugikan, dan merusak rasa keadilan, selanjutnya manusia tersebut mempengaruhi manusia yang ada disekitarnya dan lingkungannya dalam memenuhi kebutuhan fisik, mental, dan sosial.

Berbagai kasus perempuan yang diperdagangkan seringkali mereka di pekerjakan di sektor yang berbahaya, pekerjaan terlarang, kurir narkoba, untuk kerja paksa, pembantu rumah tangga, korban di eksploitasi seksual dalam pornografi, prostitusi. Upaya penanggulangan digalang melalui berbagai instrumen hukum, konvensi international, dan perjanjian multilateral.

Dari latar belakang diatas maka disusunlah suatu rumusan masalah, agar pembahasan lebih fokus dan sesuai pada persoalan tentang kajian terhadap korban dalam vonis hakim, selanjutnya akan dibahas sesuai sub kajian yaitu kasus posisi, pertimbangan dan putusan hakim, serta analisa terhadap korban dalam vonis hakim pada Putusan Hakim nomor 889/Pid.Sus/2018/PN Sda.

\section{B. METODE PENELITIAN}

Metode penelitian yang dipergunakan adalah metode penelitian hukum normatif (legal research) dilakukan dengan mengkaji norma, yang ada dalam Peraturan Perundang-undangan dan Putusan Pengadilan.

Pendekatan masalah yang dilakukan dengan menggunakan pendekatan perundang-undangan (statute approach) yang mengkaji peraturan perundang- 
undangan yang relevan serta asas-asas perundang-undangan dan pendekatan kasus (cases approach), yang mengkaji putusan pengadilan berkenaan dengan kasus threesome di Pengadilan Negeri Sidoarjo.

Prosedur pengumpulan bahan hukum dilakukan dengan melakukan sistemisasi bahan hukum, yang diperoleh melalui sumber kepustakaan. Pengelolaan dan analisis bahan hukum melalui sistematisasi lalu dilakukan analisis dengan menggunakan deskriptif analisis, yaitu menjelaskan hasil analisis terhadap posisi korban dan terhadap penerapan hukum dalam putusan hakim terhadap layanan seks menyimpang (threesome) di Pengadilan Negeri Sidoarjo.

\section{ANALISIS DAN PEMBAHASAN}

Berkaitan maraknya layanan seks menyimpang yaitu threesome, maka dalam tulisan ini penulis akan mengkaji satu kasus suami jual istri yang terjadi di Pengadilan Negeri Sidoarjo berdasarkan putusan nomor 889/Pid.Sus/2018/PN SDA, dengan kasus posisi sebagai berikut.

Kejadian tersebut berawal ketika terdakwa berniat mencari keuntungan memperdagangkan dan memanfaatkan istrinya secara komersial dengan cara terdakwa menawarkan jasa pijat dan berhubungan badan secara threesome (bertiga) antara terdakwa, istrinya yakni saksi Aminah, dan pelanggan yang bersangkutan. Terdakwa mengupayakan jasa tersebut dengan memanfaatkan media sosial berupa Facebook yang mana terdakwa membuat akun menggunakan nama samaran. Dari akun tersebut terdakwa bergabung di beberapa grup tertutup dan ditawarkan padanya jasa pijat threesome. Setelah itu, terdapat salah seorang anggota yang berminat dengan layanan pijat threesome tersebut yakni saksi Andre alias Titan sehingga terdakwa dan saksi melanjutkan obrolan melalui media Messenger (inbox) dan juga media online Whatsapp. Dari obrolan tersebut terdakwa memberikan tarif untuk layanan threesome dan apabila sudah sepakat dengan tarif threesome maka terdakwa dan pelanggan akan bertemu untuk melakukan transaksi pembayaran jasa threesome kepada terdakwa selanjutnya terdakwa membawa saksi ke rumah terdakwa serta menemui istri terdakwa untuk melakukan threesome tersebut. Adapun tarif yang dipatok terdakwa untuk layanan semalam kepada saksi disepakati sebesar Rp. 500.000,- (lima ratus ribu rupiah) dengan ketentuan Rp. 300.000,- (tiga ratus ribu rupiah) dibayar dimuka dan sisanya dibayar setelah melakukan aksinya. Dalam aksinya tersebut, terdakwa memaksa istrinya untuk mau melakukan perbuatan tersebut dan mengancam istrinya bahwa terdakwa akan memarahi istrinya dan juga upaya tersebut dilakukan adalah untuk membayar tanggungan hutang piutang yang dilakukan terdakwa. Oleh karena rasa takut, maka ia mau melakukan perbuatan tersebut. Selanjutnya pada waktu kejadian tersebut berlangsung, petugas Polresta Sidoarjo yakni saksi Tessaloni, saksi Wawan Hari Santoso, saksi Utun Utami melakukan penggrebekan dan didapati di dalam kamar tersebut yakni terdakwa beserta korban-korbannya. 
Dari kasus posisi diatas Majelis Hakim mempertimbangkan regulasi berdasarkan fakta-fakta hukum tersebut. Terdakwa dapat dinyatakan telah melakukan tindak pidana yang didakwakan kepadanya. Terhadap unsur-unsur tersebut Majelis Hakim mempertimbangkan terdakwa sebagai subyek hukum yang akan dimintai tanggung jawab terhadap perbuatan-perbuatan pidana yang didakwakan oleh Penuntut Umum. Terdakwa dengan identitas sebagaimana tersebut dalam surat dakwaan adalah orang yang disidik dan diajukan ke persidangan sehingga tidak akan terjadi kekeliruan mengenai orang dan terdakwa dalam kondisi sehat jasmani dan rohani, yang dapat dipertanggungjawabkan apabila perbuatannya terbukti.

Berdasarkan fakta-fakta yang telah dipertimbangkan diatas, terungkap terdakwa telah melakukan penyalahgunaan kekuasaan terhadap istrinya yaitu saksi dan korban untuk tujuan mengeksploitasi dengan cara mempengaruhi istrinya atas alasan ekonomi sehingga mendapat persetujuan dari korban dan korban bersedia melakukan hal tersebut. Oleh karena itu maka terdakwa haruslah dinyatakan telah terbukti secara sah dan meyakinkan melakukan tindak pidana sebagaimana didakwakan.

Selama melakukan pemeriksaan terhadap terdakwa dipersidangan tidak ditemukan adanya alasan-alasan pemaaf dan pembenar, maka menurut hukum terdakwa mampu bertanggung jawab dan harus dinyatakan bersalah serta dijatuhi pidana yang setimpal dengan perbuatannya. Dalam perkara ini terhadap terdakwa dikenakan penangkapan dan penahanan yang sah, maka masa penangkapan serta penahanan tersebut harus dikurangkan seluruhnya dari pidana yang dijatuhkan.

Memperhatikan Pasal 2 UU RI No. 21 Tahun 2007 tentang Tindak Pidana Perdagangan Orang, Undang-Undang RI Nomor 8 Tahun 1981 tentang Hukum Acara Pidana serta peraturan perundang-undangan lain yang berhubungan dengan perkara ini, Majelis Hakim memutuskan:

1. Menyatakan terdakwa terbukti secara sah dan meyakinkan bersalah melakukan tindak pidana "perdagangan orang";

2. Menjatuhkan pidana terhadap terdakwa dengan pidana penjara selama 4 (empat) tahun 6 (enam) bulan dan denda sejumlah Rp. 120.000.000,- (seratus dua puluh juta rupiah), dengan ketentuan apabila denda tidak dibayar, maka diganti dengan pidana kurungan selama 3 (tiga) bulan;

3. Menetapkan lamanya masa penangkapan dan penahanan yang telah dijalani oleh terdakwa, dikurangkan seluruhnya dari pidana yang dijatuhkan;

4. Menetapkan terdakwa tetap ditahan.

\section{Analisis Terhadap Vonis Hakim dan Korban}

Menurut kajian hukum pidana material, bahwa atas kasus posisi diatas hakim memutus dengan menggunakan UU TPPO kurang tepat. Karena antara pelaku dan korban masih ada ikatan perkawinan atau sebagai suami dan istri yang sah, sehingga berimplikasi pada pemberian sanksi kepada terdakwa terlalu berat, yaitu 4 (empat) 
tahun 6 (enam) bulan dan denda sebesar Rp 120.000.000 (Seratus Dua Puluh Juta Rupiah).

Secara yuridis, penerapan hukum terhadap kasus diatas dengan menggunakan Undang-undang No. 23 Tahun 2004 tentang Penghapusan Kekerasan Dalam Rumah Tangga (UU PKDRT), pada Pasal 8 huruf $\mathrm{b}$ menyatakan bahwa "Pemaksaan hubungan seksual terhadap salah seorang dalam lingkup rumah tangganya dengan orang lain untuk tujuan komersial dan/atau tujuan tertentu". Lalu dilanjutkan pada penjelasan Pasal 8 disebutkan bahwa yang dimaksud dengan kekerasan seksual dalam ketentuan ini adalah setiap perbuatan yang berupa pemaksaan hubungan seksual, pemaksaan hubungan seksual dengan cara tidak wajar dan/atau tidak disukai, pemaksaan hubungan seksual dengan orang lain untuk tujuan komersial dan/atau tujuan tertentu dan sanksi terhadap ketentuan Pasal 8 ayat (2) sebagaimana diatur dalam Pasal 47, bahwa:

"Setiap orang yang memaksa orang yang menetap dalam rumah tangganya melakukan hubungan seksual sebagaimana dimaksud dalam Pasal 8 huruf b dipidana dengan penjara paling singkat 4 (empat) tahun dan pidana penjara paling lama 15 (lima belas) tahun atau denda paling sedikit Rp. 12 juta atau denda paling banyak Rp300.000.000.

Menurut kajian viktimologi yang melandaskan pada korban kejahatan, dalam hal ini hakim dalam menjatuhkan putusannya harus memperhatikan kepentingan umum, masyarakat ataupun kepentingan pihak yang dirugikan.

Posisi korban kejahatan yang pada dasarnya merupakan pihak yang paling menderita dalam suatu tindak pidana, belum memperoleh perlindungan memadai seperti yang diberikan oleh undang-undang kepada pelaku kejahatan. Akibatnya, pada saat pelaku kejahatan telah dijatuhi sanksi pidana oleh pengadilan, kondisi korban kejahatan seperti tidak dipedulikan sama sekali. Padahal masalah keadilan dan penghormatan hak asasi manusia tidak hanya berlaku terhadap pelaku kejahatan saja, tetapi juga korban kejahatan.

Penyebab seseorang dapat menjadi korban kejahatan adalah kealphaan, ketidaktahuan, kurang hati-hati, kelemahan korban. Penyebab lain adalah faktor perkembangan global, faktor ekonomi, politik, sosiologi, ataupun faktor-faktor negatif lainnya. Korban dapat menjadi korban murni, artinya korban memang tidak bersalah, atau dapat menjadi korban tidak murni yaitu korban tersangkut atau menjadi bagian dari pelaku kejahatan, bahkan sekaligus menjadi pelakunya. ${ }^{2}$

Terhadap perlindungannya Muladi dalam (Yulia) ${ }^{3}$, mengemukakan beberapa alasan yang bertalian dengan perlindungan korban, yaitu; Pertama, membaginya dalam dua hal yaitu proses pemidanaan dalam arti umum merupakan wewenang pembuat undang-undang, sesuai dengan asas legalitas, yang menegaskan bahwa baik poena maupun crimen harus diterapkan terlebih dahulu apabila hendak menjatuhkan pidana atas diri seorang pelaku tindak pidana, dan proses pidana dalam arti konkret adalah

2Liata Vina Tania, 2018, Analisis Perspektif Viktimologi Terhadap Korban Tindak Pidana Pemalsuan Dokumen Tenaga Kerja Wanita, Jurnal Fakultas Hukum, Universitas Lampung Bandar Lampung, h. 2

${ }^{3}$ Rena Yulia, 2015, h. 39 
proses pemidanaan berkaitan dengan penetapan pidana melalui infrastruktur penitensier (hakim, petugas LP, dan sebagainya).

Kedua, bertolak dari argumentasi lain yang mengedepankan perlindungan hukum bagi korban kejahatan adalah argumentasi kontrak sosial dan argumentasi solidaritas sosial. Negara lebih boleh dikatakan monopoli seluruh reaksi sosial terhadap kejahatan dan melarang tindakan yang bersifat pribadi, oleh karena itu bila terjadi kejahatan dan menimbulkan korban, negara harus bertanggung jawab untuk memperhatikan kebutuhan para korban tersebut.

Ketiga, masalah pengaturan korban kejahatan biasanya dikaitkan dengan salah satu tujuan pemidanaan, yang dewasa ini banyak dikedepankan yaitu penyelesaian konflik. Penyelesaian konflik yang ditimbulkan oleh adanya tindak pidana, memulihkan keseimbangan dan mendatangkan rasa damai dalam masyarakat.

Kekerasan yang dilakukan suami terhadap istri dalam lingkup rumah tangga adalah salah satu bentuk kekerasan terhadap perempuan yang banyak terjadi di masyarakat. Hal ini merupakan akibat dari hubungan antara laki-laki dan perempuan dalam rumah tangga ketika laki-laki lebih superior dari perempuan, sehingga membentuk sistem didalam keluarga yaitu laki-laki mengontrol perempuan, salah satunya dengan kekerasan.

Dalam sistem peradilan pidana di Indonesia, posisi Jaksa Penuntut Umum mewakili korban, maka acapkali dalam prakteknya aspirasi korban dalam proses peradilan pidana kurang diperhatikan sehingga menimbulkan ketidakpuasan diri dan atau keluarganya terhadap tuntutan jaksa dan putusan hakim. Aspek ini salah satunya dipicu karena secara prosedural korban tidak mempunyai peluang untuk menyatakan ketidakpuasannya terhadap tuntutan jaksa dan putusan hakim. Dengan titik tolak demikian maka sistem peradilan pidana hendaknya menyesuaikan, menselaraskan kualitas dan kuantitas penderitaan dan kerugian yang diderita korban. ${ }^{4}$

Dalam lingkup keluarga, kekerasan yang terjadi kaitannya dengan status dan peran yang berbeda antara suami dan istri, sehingga bentuk-bentuk kekerasannya bersifat eksploitasi dan dominasi. Perempuan tidak diberi status dan peran sesuai dengan haknya karena kontrol dalam urusan rumah tangga ada pada suami. Pada kondisi ini suami dengan mudah dapat melakukan tindak kekerasan baik secara fisik maupun psikologis, karena yang menjadi pedoman tindakan suami adalah power (kekuasaan). ${ }^{5}$

Perhatian pemerintah terhadap korban belum tampak dalam penegakan hukumnya sebagaimana disampaikan, selama ini korban kejahatan merupakan orang yang terlupakan dalam Sistem Peradilan Pidana. Pemerintah wajib memperhatikan hak-hak korban dalam mengadili suatu tindak pidana. Kepentingan korban harus

${ }^{4}$ Lilik Mulyadi, 2007, Kapita Selekta Hukum Pidana, Kriminologi, dan Viktimologi, Penerbit PT Djambatan, Jakarta, h. 122-123

${ }^{5}$ Siti Homzah, 2010, Kekerasan terhadap Perempuan dalam Perspektif Gender, dalam Munandar Sulaiman dan Siti Homzah, Kekerasan terhadap Perempuan Tinjauan dalam berbagai disiplin Ilmu dan Kasus Kekerasan, Refika Aditama, h.4 
diberikan dalam penanganan perkara pidana selain sebagai saksi yang mengetahui terjadinya suatu kejahatan juga karena kedudukan korban sebagai subyek hukum yang memiliki kedudukan sederajat didepan hukum (equality before the law).

Terhadap kasus diatas hakim sebelum menjatuhkan sanksi, harus lebih teliti dan cermat dalam penerapan undang-undang serta memperhatikan hati nurani korban (istri), agar pengadilan sebagai lembaga yang memberikan rasa keadilan bisa terwujud. Tidak hanya memperhatikan hukum secara normatif (keadilan struktural) namun juga memperhatikan keadilan substantif yang bisa dirasakan oleh pencari keadilan.

Suatu penyelesaian perkara pidana banyak ditemukan korban kejahatan kurang memperoleh perlindungan hukum yang memadai baik perlindungan yang sifatnya immateriil maupun materiil. Korban kejahatan ditempatkan sebagai alat bukti yang memberi keterangan. ${ }^{6}$

Pasal 133 Rancangan KUHP tahun 20157, telah mengakomodir kepentingan korban kejahatan dapat memperolah ganti kerugian materiil dari pelaku tindak pidana berdasarkan putusan pengadilan, namun putusan hakim pengadilan belum memperhatikan korban yang masih ada hubungan keluarga (istri) berdasarkan putusan pengadilan, akan bertanggung jawab membayar pidana denda terhadap suaminya.

\section{KESIMPULAN}

Setelah mengkaji kasus posisi dengan beberapa kajian pustaka dan menganalisisnya maka penulis berkesimpulan bahwa perbuatan suami menjual istrinya untuk melakukan layanan sex menyimpang yang dalam hal ini adalah threesome tidak termasuk dalam tindak pidana perdagangan orang, karena secara normatif sangat tidak relevan, sehingga sanksi penjara 4 (empat) tahun, 6 (enam) bulan dan denda sebesar Rp120.000.000 adalah kurang tepat, karena korban masih dalam

${ }^{6}$ Arif Gosita, 1989, Masalah Perlindungan Anak, CV Akademika Pressindo, Jakarta, h. 94

7Pasal 133 RKUHP tahun 2015 meyebutkan bahwa :

(1) Apabila terdakwa dijatuhi pidana dan terdapat korban yang menderita kerugian material akibat tindak pidana yang dilakukan oleh terdakwa, hakim mengharuskan terpidana membayar ganti kerugian kepada korban yang besarnya ditentukan dalam putusannya ;

(2) Apabila terpidana tidak membayar ganti kerugian sebagaimana dimaksud pada ayat (1), harta benda terpidana disita dan dilelang untuk membayar ganti kerugian kepada korban ;

(3) Apabila terpidana berupaya menghindar untuk membayar kompensasi kepada korban, terpidana tidak berhak mendapatkan pengurangan masa pidana dan tidak mendapatkan pembebasan bersyarat ;

(4) Dalam penjatuhan pidana bersyarat dapat ditentukan syarat khusus berupa kewajiban terpidana untuk membayar ganti kerugian kepada korban ;

(5) Ketentuan lebih lanjut mengenai syarat dan tata cara penyitaan dan pelelangan sebagaimana dimaksud pada ayat (2) diatur dengan Peraturan Pemerintah. 


\section{A Djoko Sumaryanto}

ikatan hubungan suami istri sehingga tidak sepenuhnya dikatakan sebagai perdagangan perempuan.

\section{REFERENSI}

Tanya BL, Simanjuntak YN, Hage MY. Teori-teori Hukum: Strategi Tertib Manusia Lintas Ruang dan Generasi. Yogyakarta: Genta Publishing; 2010.

IOM Indonesia. Fenomena Trafficking Manusia dan Konteks Hukum Internasional. Jakarta: IOM Indonesia; 2006.

IOM Indonesia. Combating Human Trafficking Through Law Enforcement. Jakarta: IOM Indonesia; 2006.

Watuliu T. Strategi Polri Penanggulangan Kejahatan Human Trafficking. In: Makalah Seminar Perbudakan Manusia Pada Abad Modern di Indonesia dan Upaya Penanggulangannya. 2006.

Yulia R. Victimologi, Perlindungan Hukum Terhadap Korban Kejahatan. Graha Ilmu; 2010.

Meilisa H. Istri yang Dijual Suami untuk Threesome di Sarangan Hamil 6 Bulan. Detik News [Internet]. 2019; Available from: https://news.detik.com/berita-jawatimur/d-4668648/istri-yang-dijual-suami-untuk-threesome-di-sarangan-hamil-6bulan

Ridho R. Polisi Bongkar Praktik Prostitusi Threesome di Serang, Tarif Rp1 Juta per Kencan. Inews [Internet]. 2019 Sep; Available from: https://regional.inews.id/berita/polisi-bongkar-praktik-prostitusi-threesome-diserang-tarif-rp1-juta-per-kencan

Yulia R. Mengkaji Kembali Posisi Korban Kejahatan Dalam Sistem Peradilan Pidana. Mimb Huk - Fak Huk Univ Gadjah Mada. 2016;

Sapardjaja KE. Ajaran Sifat Melawan Hukum Materiil dalam Hukum Pidana. Alumni Bandung; 2002.

Tania LV, Siswanto H, Andrisman T. Analisis Perspektif Viktimologis Terhadap Korban Tindak Pidana Pemalsuan Dokumen Tenaga Kerja Wanita. Poenale J Bagian Huk Pidana. 2018;

11. Santoso L, Arifin B. Perlindungan Perempuan Korban Kekerasan Perspektif Hukum Islam. J Jure. 2017;

Hajon PM. Perlindungan Hukum Bagi Rakyat. Surabaya: Bina Ilmu; 1987.

Mulyadi L. Kapita Selekta Hukum Pidana, Kriminologi, dan Viktimologi. Jakarta: PT Djambatan; 2007.

Sulaiman M, Homzah S. Kekerasan terhadap Perempuan Tinjauan dalam berbagai disiplin Ilmu dan Kasus Kekesaran. Refika Aditama; 2010.

Gosita A. Masalah Perlindungan Anak. Jakarta: CV Akademika Pressindo; 1989. 